\title{
高窒素オーステナイト系ステンレス鋼における $\mathrm{Mn}$ 添加による相変態機構の遷移
}

\author{
古賀 紀光 ${ }^{1)} \cdot$ 福山 道紀 ${ }^{2)} \cdot$ 中田 伸生 ${ }^{3,4)} \cdot$ 土山 聡宏 ${ }^{3,4) *} \cdot$ 高木 節雄 ${ }^{3,4)}$
}

Transition of Phase Transformation Mechanism by Mn addition in High Nitrogen Austenitic Stainless Steel

Norimitsu Koga, Michinori Fukuyama, Nobuo NaKada, Toshihiro Tsuchiyama and Setsuo TaKaki

Synopsis : Fe-25Cr-1N-0, 2, 5Mn mass\% alloys were subjected to isothermal heat treatment, and their microstructure formation and phase transformation behavior were investigated in order to clarify the effect of Mn addition on the transformation mechanism of high nitrogen austenite. Microstructure observation for the $1073 \mathrm{~K}$ heat-treated specimens revealed that the $\mathrm{Fe}-25 \mathrm{Cr}-1 \mathrm{~N}$ alloy exhibited $\left(\alpha+\mathrm{Cr}_{2} \mathrm{~N}\right) \mathrm{lamellar}$ eutectoid structure, while the Fe-25Cr-1N-2Mn and -5Mn alloys did finer $\left(\alpha^{\prime}\right.$ (or retained $\left.\left.\gamma\right)+\mathrm{Cr}_{2} \mathrm{~N}\right)$ lamellar structure as well as $\left(\alpha+\mathrm{Cr}_{2} \mathrm{~N}\right)$ lamellar eutectoid structure. It was suggested that the $\left(\alpha^{\prime}+\mathrm{Cr}_{2} \mathrm{~N}\right)$ lamellar structure had been formed through $\gamma_{1} \rightarrow \gamma_{2}+\mathrm{Cr}_{2} \mathrm{~N}$ cellular precipitation followed by martensitic transformation of $\gamma_{2}$ on cooling to ambient temperature. Nitrogen concentration in untransformed austenite in the Fe-25Cr-1N$2 \mathrm{Mn}$ and $-5 \mathrm{Mn}$ alloys was continuously decreased with progressing of $\left(\gamma+\mathrm{Cr}_{2} \mathrm{~N}\right)$ cellular precipitation due to nitrogen long-range diffusion from untransformed austenite to $\left(\gamma+\mathrm{Cr}_{2} \mathrm{~N}\right)$ cellular structure. As a result of decreased nitrogen concentration in untransformed austenite, transformation mechanism switched from $\left(\gamma+\mathrm{Cr}_{2} \mathrm{~N}\right)$ cellular precipitation to $\left(\alpha+\mathrm{Cr}_{2} \mathrm{~N}\right)$ eutectoid transformation.

Key words: high nitrogen austenitic stainless steel; isothermal transformation; $\left(\alpha+\mathrm{Cr}_{2} \mathrm{~N}\right)$ eutectoid transformation; $\left(\gamma+\mathrm{Cr}_{2} \mathrm{~N}\right)$ cellular precipitation; $\left(\alpha^{\prime}+\mathrm{Cr}_{2} \mathrm{~N}\right)$ lamellar structure.

\section{1. 緒言}

$\mathrm{Ni}$ フリー高窒素オーステナイト系ステンレス鋼として 知られている Fe-Cr-Mn-N系合金は, 窒素の固溶により高 強度かつ高耐食性を有しており ${ }^{1,2}$, 構造用高強度非磁性 鋼, Niアレルギーを起こさない生体材料としての応用が期 待されている。しかし, 本合金のオーステナイト組織は熱 的に不安定であり, 熱処理や溶接後の冷却速度が不十分で あると窒化物の析出やオーステナイトの分解が生じ ${ }^{3)}$, 脆 化や耐食性の劣化を引き起こすという問題点がある。一 方, この性質を逆に有効利用して機械的性質を改善する手 法として, 分解したオーステナイトの逆変態処理による結 晶粒微細化法も提案されている ${ }^{4)}$ 。以上のような工業的重 要性の観点から, 高窒素オーステナイトの相変態挙動に関 する研究は過去にも実施されてきたが, その相変態機構や それに及ぼす合金元素の影響は必ずしも明らかになってい ない。

著者らは, Mnを含有しない $\mathrm{Fe}-25 \mathrm{mass} \% \mathrm{Cr}-1 \mathrm{mass} \% \mathrm{~N}$ (以 下，化学組成は mass \%を示す) 合金の恒温変態挙動につい
て調査し, 本鋼のオーステナイトを $1000 \mathrm{~K}$ 付近で恒温保持 すると, 共析変態によりフェライトと $\mathrm{Cr}_{2} \mathrm{~N}$ への分解が生 じ, Fe-C合金に打けるパーライトに類似したラメラ組織が 形成されることを明らかにした ${ }^{5)}$ 。一方, Mnが添加された 各種の Fe-Cr-Mn-N合金においても恒温変態によってラメ ラ状窒化物の析出が生じることが報告されている ${ }^{6-8)}$ 。し かしながら, この Fe-Cr-Mn-N合金で形成されるラメラ組 織内の母相はf fcc相であり, Fe-Cr-N合金における共析変態 とは本質的に異なる $\gamma_{1} \rightarrow \gamma_{2}+\mathrm{Cr}_{2} \mathrm{~N}$ セル状析出 ${ }^{9)}$ が生じた と判断される。なお， $\gamma_{1}$ と $\gamma_{2}$ はいずれも fcc構造を有する オーステナイトであるが, 窒素濃度の違いがあるため添え 字によって区別している。このようなセル状析出はFe-Cr$\mathrm{Ni}-\mathrm{N}$ 系合金においても確認されており ${ }^{10)}, \mathrm{Mn}$ や $\mathrm{Ni}$ な゙の オーステナイト安定化元素の添加が相変態機構を共析変態 からセル状析出に変化させたと考えられるが, 本系合金に おける相変態機構と合金元素濃度の関係が系統的に調査さ れた例はない。

本研究では, Niフリー高窒素オーステナイト系ステンレ ス鋼の相変態機構に及ぼす Mn 濃度の影響を明らかにする

平成26年2月10日受付 平成26年4月18日受理 (Received on Feb. 10, 2014 ; Accepted on Apr. 18, 2014)

1) 九州大学大学院生 (現: 横浜国立大学大学院工学研究院) (Graduate school of engineering, Kyushu University, now Department of Materials Science and Engineering, Yokohama National University, 79-5 Tokiwadai Hodogaya Yokohama 240850)

2）九州大学大学院生 (現: 愛知製鋼 (株)) (Graduate Student, Kyushu University, now Aichi steel, Ltd.)

3) 九州大学大学院工学研究院材料工学部門 (Department of Materials Science and Engineering, Kyushu University)

4）九州大学カーボンニュートラル・エネルギー国際研究所 (International Institute for Carbon-Neutral Energy Research (WPI-I2CNER), Kyushu University)

* Corresponding author : E-mail : toshi@zaiko.kyushu-u.ac.jp

DOI : http://dx.doi.org/10.2355/tetsutohagane.100.1165 
ため, Mn 量を変化させた Fe-25Cr-1N-Mn合金を作製し，恒 温変態に伴う組織変化および相変態挙動について調査を 行った。そして窒素の拡散および分配挙動, 形成組織の結 晶学的特徴の観点から相変態機構について考察した。

\section{2. 実験方法}

供試材として, Mn 量を $0,2,5 \%$ に変化させた $25 \mathrm{Cr}$ フェ ライト系ステンレス鋼を母材とし，それらに固相窒素吸収 法 (高温 $\mathrm{N}_{2}$ ガス䨌囲気での熱処理 ${ }^{11}$ ) ) 適用して窒素を添 加した試料を使用した。固相窒素吸収処理で母材へ吸収さ れる $\mathrm{N}$ の平衡量は $\mathrm{Mn}$ と $\mathrm{Cr}$ 濃度で決定され ${ }^{11)}$, さらに圧力 の $1 / 2$ 乗に比例することが明らかとなっている (Sievert's $\left.\mathrm{law}^{12)}\right)$ 。そこで，すべての鋼種で窒素量を一定とするため Mn 量に応じて窒素分圧をそれぞれ0.100，0.085，0.067 MPa と変化させ， $1473 \mathrm{~K} て ゙ 86.4 \mathrm{ks}$ の固相窒素吸収処理を行い, 窒素を平衡量まで吸収させた。以上のように作製した $\mathrm{Fe}$ $25 \mathrm{Cr}-0,2,5 \mathrm{Mn}-1.1 \mathrm{~N}$ 合金 (0Mn 鋼, $2 \mathrm{Mn}$ 鋼, $5 \mathrm{Mn}$ 鋼) の化 学組成を Table 1 に示す。窒素吸収処理後の試料は, 全ての 合金でオーステナイト単相組織を形成していた。次いで,

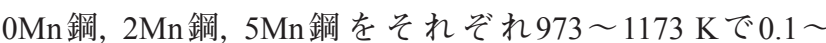
$21.6 \mathrm{ks}$ の恒温保持後水冷した。

組織観察には光学顕微鏡 (光顕), 透過型電子顕微鏡 (TEM), 電解放出型走査電子顕微鏡 (FE-SEM) を使用し た。結晶方位解析にはFE-SEMに搭載された方位像顕微 鏡 $(\mathrm{OIM})$ を用いた後方散乱電子線回折 (EBSD) 法を用い た。窒素濃度分布解析には電子プローブマイクロアナライ ザ（EPMA）を使用した。光顕およびSEM観察用の試料に ついては，エメリー紙による湿式研磨およびアルミナ懸濁 液によるバフ研磨後，数滴の塩酸を加えた $3 \%$ ピクリン酸 アルコール溶液で腐食を行い作製した。TEM観察用薄膜試 料については, バルク材から放電加工により切り出した $\phi$ $3 \mathrm{~mm}$ の試料を厚さ $0.1 \mathrm{~mm}$ まで湿式研磨後, $10 \%$ 過塩素酸 －90\%酢酸混合溶液を用いたツインジェット研磨法によ り作製した。EBSD およびEPMA解析には，湿式研磨後に ダイヤモンド研磨およびコロイダルシリカ研磨により仕上 げた試料を用いた。相の同定にはX線回折法 $(\mathrm{Co}-\mathrm{K} \alpha)$ を 用いた。X線回折用の試料については，光顕観察の場合と 同様に研磨した後，リン酸クロム酸溶液 $\left(\mathrm{H}_{3} \mathrm{PO}_{4}: 500 \mathrm{~g}+\right.$

Table 1. Chemical compositions of the steels used in this study.

\begin{tabular}{ccccccccc}
\hline & $\mathrm{N}$ & $\mathrm{C}$ & $\mathrm{Si}$ & $\mathrm{Mn}$ & $\mathrm{Ni}$ & $\mathrm{Cr}$ & $\mathrm{Mo}$ & $\mathrm{Fe}$ \\
\hline $\begin{array}{c}0 \mathrm{Mn} \\
\text { steel }\end{array}$ & 1.11 & 0.002 & $<0.01$ & $<0.01$ & $<0.01$ & 25.11 & $<0.01$ & Bal. \\
\hline $\begin{array}{c}2 \mathrm{Mn} \\
\text { steel }\end{array}$ & 1.14 & 0.021 & 0.33 & 1.99 & 0.49 & 24.93 & 0.09 & Bal. \\
\hline $\begin{array}{l}5 \mathrm{Mn} \\
\text { steel }\end{array}$ & 1.13 & 0.002 & $<0.01$ & 5.09 & $<0.01$ & 24.99 & $<0.01$ & Bal.
\end{tabular}

$\left.\mathrm{Cr}_{2} \mathrm{O}_{3}: 250 \mathrm{~g}\right)$ を用いた電解研磨により作製した。各試料の オーステナイトからマルテンサイトへの変態開始温度 $\left(\mathrm{M}_{\mathrm{s}}\right.$ 点) および変態終了温度 $\left(\mathrm{M}_{\mathrm{f}}\right.$ 点) を測定するため熱膨張試 験を行った。試験には幅 $8 \mathrm{~mm}$, 高さ $10 \mathrm{~mm}$ のサイズに切り 出した試料を用い，アルゴンガス雰囲気中にて $100 \mathrm{~K} / \mathrm{min}$ で $1073 \mathrm{~K}$ まで昇温後 $0.6 \sim 10.8 \mathrm{ks}$ の恒温保持, 次いで 10 K/min で253〜 $273 \mathrm{~K}$ まで冷却される際の試験片長さの変化 から変態点を測定した。試料の硬さ測定にはマイクロビッ カース硬さ試験機（AKASI MICROHARDNESS）を使用し， 光顕観察の場合と同様の研磨を施した試料について, 荷重 0.49 2.94 N，負荷時間 $15 \mathrm{~s}$ の条件で測定を行った。

\section{3. 実験結果}

\section{$3 \cdot 1$ 恒温時効に伴う組織変化}

Fig. 1 は，1073 Kで種々の時間恒温保持した試料の光顕 組織を示している。写真中の白い領域は未変態オーステナ イトに，黒い領域は変態生成物にそれぞれ対応している。 いずれの鋼種においても，変態生成物はオーステナイト粒 界上から優先的に核生成する傾向にあるが，0Mn鋼に関し ては粒内でも塊状の析出が確認される。変態挙動に若干の 差異はあるものの，いずれの試料においても最終的には相 変態が完了し，試料全面が変態生成物で覆われるようにな る。Fig.2は，恒温変態が完了していた各試料のX線回折よ り得られた回折パターンを示す。いずれの鋼種においても 時効前に存在していたオーステナイト相は消失，または減 少しており，それに代わってフェライト相と窒化物 $\left(\mathrm{Cr}_{2} \mathrm{~N}\right)$ 相が析出していることがわかる。 $5 \mathrm{Mn}$ 鋼 $(\mathrm{c})$ においては変 態が完了しているにも関わらずオーステナイト相のピーク が表れているが，この理由については，後述するように， オーステナイト $\left(\gamma_{1}\right)$ から窒素濃度の異なるオーステナイ 卜 $\left(\gamma_{2}\right)$ と $\mathrm{Cr}_{2} \mathrm{~N}$ がセル状に析出し，その $\gamma_{2}$ が検出されたも のである。Fig.3は，種々の温度，時間で恒温保持を行った

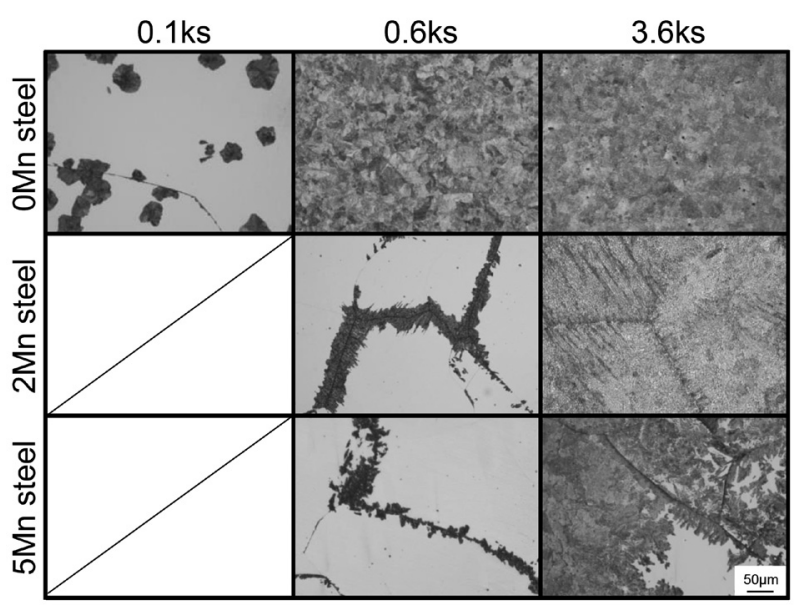

Fig. 1. Optical micrographs of the specimens isothermally heattreated at $1073 \mathrm{~K}$ for various time. 
試料の光顕観察結果をもとに作成した恒温変態線図 (TimeTemperature-Transformation diagram；TTT図）を示している。 $0 \mathrm{Mn}$ 鋼の TTT 図は明瞭な C曲線を呈しており, $1100 \mathrm{~K}$ 付近 にnoseが存在していることがわかる。一方, $2 \mathrm{Mn}$ 鋼および $5 \mathrm{Mn}$ 鋼では nose は確認できなかったが, 保持温度の低下に 伴い変態開始時間 $\left(\mathrm{T}_{\mathrm{s}}\right)$ および終了時間 $\left(\mathrm{T}_{\mathrm{f}}\right)$ が長時間側に 移行している。ここで, $\mathrm{Mn}$ 量の増加に伴い変態完了を示 す $\mathrm{T}_{\mathrm{f}}$ 線が長時間側に大きく移行しており, Mn添加によっ て変態の進行が遅延されることがわかる。ただし $\mathrm{T}_{\mathrm{s}}$ 線に関 しては低温側で逆転が生じており, $2 \mathrm{Mn}$ 鋼の $\mathrm{T}_{\mathrm{s}}$ 線が $5 \mathrm{Mn}$ 鋼 のそれより長時間側に存在している。この理由は定かでは ないが, Table 1 に示すように $2 \mathrm{Mn}$ 鋼では Ni, Si, Moなどの 合金元素量が他の鋼種と比べてやや高めであり，これらの 微量合金元素が変態開始を遅らせた可能性がある。

Fig.4は，1073 Kに打ける恒温変態終了後の各試料の SEM組織を示す。いずれの鋼種においてもラメラ組織を形 成していることが分かるが，それぞれの鋼種で析出相の分 布には明瞭な差異が見られる。0Mn鋼 (a) で観察される均 一なラメラ組織は, Nakada らによって報告されている（ $\alpha$ $\left.+\mathrm{Cr}_{2} \mathrm{~N}\right)$ 共析組織 ${ }^{4)}$ に対応するが (ここで $\alpha$ はフェライト

\section{(a) OMn steel (1073K-0.6ks)}

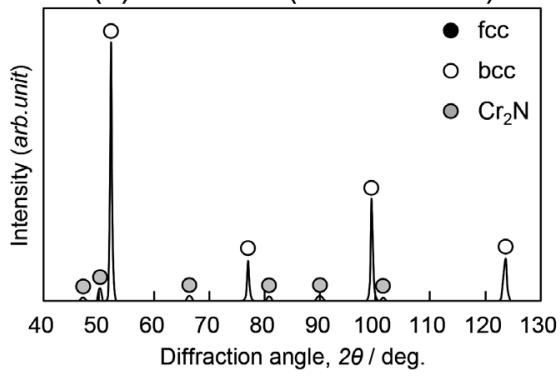

(b) $2 \mathrm{Mn}$ steel $(1073 \mathrm{~K}-3.6 \mathrm{ks})$

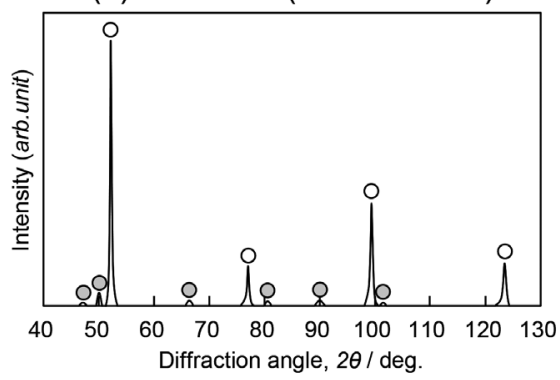

(c) $5 \mathrm{Mn}$ steel $(1073 \mathrm{~K}-10.8 \mathrm{ks})$

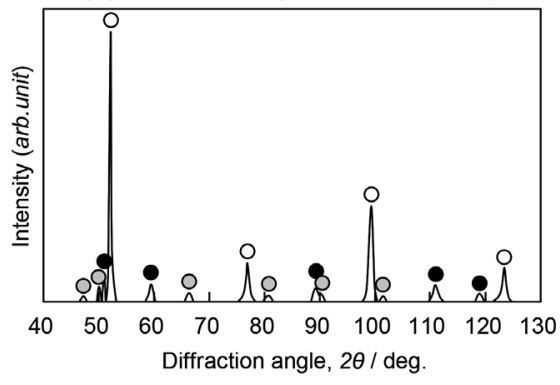

Fig. 2. X-ray diffraction patterns in the specimens in which transformation has completed.
を示す), $2 \mathrm{Mn}$ 鋼 (b) および $5 \mathrm{Mn}$ 鋼 (c) については, 四中に 示す黒実線を境に組織が大きく異なっている。2Mn鋼 (b) では, 四中破線で示す旧オーステナイト粒界近傍の黒実線 内部で微細なラメラ組織が, 外部では粗大なラメラ組織が 形成されている。 $5 \mathrm{Mn}$ 鋼 (c) では, 微細ラメラ組織の領域 と, ラメラ組織が形成されずに窒化物がまばらに分散して いる領域が混在している。各組織に対して硬さを測定した 結果, 粗大ラメラ組織の領域および窒化物がまばらに分散 した領域の硬さは約 $3.0 \mathrm{GPa}$ であった。これは, $0 \mathrm{Mn}$ 鋼の共 析組織の硬さ $3.0 \mathrm{GPa}$ と同程度である。一方, 微細ラメラ組 織の領域の硬さは4.9 GPaであり, 上述の共析組織に比べ て著しく高い值を示すことがわかった。ここで，TEMによ りラメラ組織内部の観察を行った結果を Fig.5 に示す。 $0 \mathrm{Mn}$ 鋼（a）では試料全面で転位密度が低いフェライトを母相と する組織が観察され, 本ラメラ組織が共析変態により形成 されたことが再確認された。一方, $2 \mathrm{Mn}$ 鋼 (b) および $5 \mathrm{Mn}$ 鋼 (c) においても図中黒矢印で示すように粗大なラメラ組 織内，ならびに窒化物がまばらに分散した領域では，0Mn 鋼と同様に転位密度の低いフェライト組織が観察される が, 図中白矢印で示す微細ラメラ組織の領域では高密度の 転位が観察される。この組織は, 結晶構造がフェライト組 織と同様にbccであったことから, 恒温変態後の冷却時に 生成したマルテンサイトであると推察される。そこで, 恒 温変態後の冷却時の変態挙動を調査した。各鋼種について $1073 \mathrm{~K}$ で恒温変態を完了させた後の冷却過程における熱 収縮曲線を Fig.6に示す。まず恒温変態を終了させた時点 での $1073 \mathrm{~K}$ での変位量 $(1073 \mathrm{~K})$ に着目すると, 鋼種によっ てその值が異なっており，Mn量が低いものほど大きく なっていることがわかる。これは体積膨張を伴う $\gamma \rightarrow \alpha+$ $\mathrm{Cr}_{2} \mathrm{~N}$ 共析変態の割合が異なっていることに対応している。 すなわち, $0 \mathrm{Mn}$ 鋼では試料全体が $\left(\alpha+\mathrm{Cr}_{2} \mathrm{~N}\right)$ 組織となっ ているため, 最も変位量が大きい。同鋼では，冷却過程で 相変態は起こらないが, $2 \mathrm{Mn}$ 鋼および $5 \mathrm{Mn}$ 鋼では, いずれ も冷却中に膨張が確認され，マルテンサイト変態を生じて いることが確認された。各鋼のMs点およびMf点は，それ ぞれ $2 \mathrm{Mn}$ 鋼では $500 \mathrm{~K}$ および $420 \mathrm{~K}, 5 \mathrm{Mn}$ 鋼では $380 \mathrm{~K} お よ$

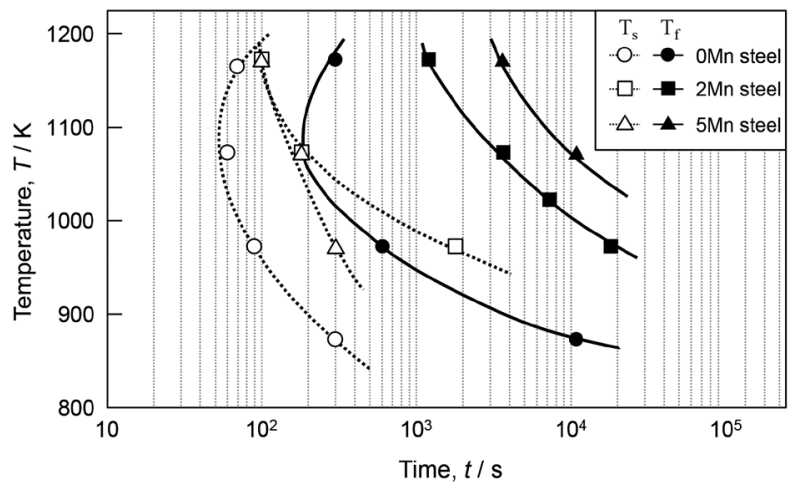

Fig. 3. TTT diagrams of the $0 \mathrm{Mn}, 2 \mathrm{Mn}$ and $5 \mathrm{Mn}$ steels. 
(a) $0 \mathrm{Mn}$ steel $(1073 \mathrm{~K}-0.6 \mathrm{ks})$

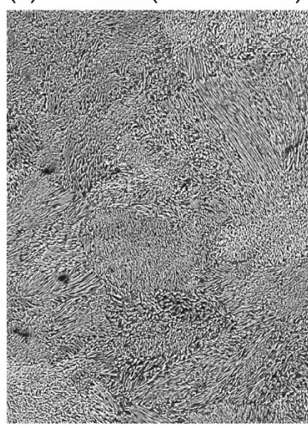

(b) $2 \mathrm{Mn}$ steel $(1073 \mathrm{~K}-3.6 \mathrm{ks})$

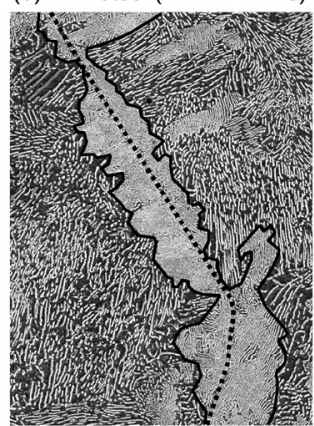

(c) $5 \mathrm{Mn}$ steel $(1073 \mathrm{~K}-10.8 \mathrm{ks})$

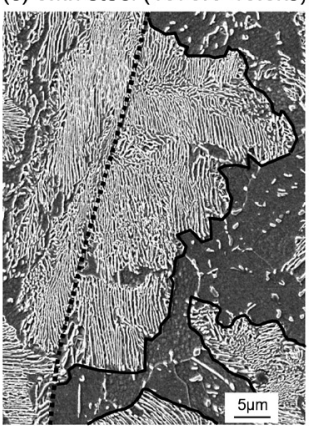

Fig. 4. SEM images in the specimens in which transformation has completed. Broken and solid lines indicate prior austenite grain boundaries and boundaries between fine and coarse lamellar structures, respectively.

(a) $0 \mathrm{Mn}$ steel $(1073 \mathrm{~K}-0.6 \mathrm{ks})$

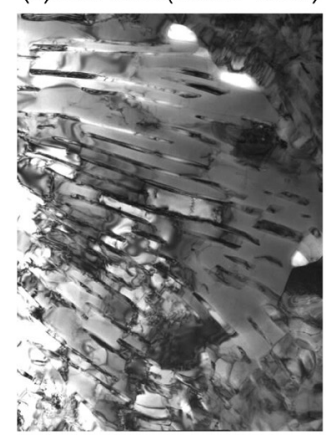

(b) $2 \mathrm{Mn}$ steel (1073K-3.6ks)

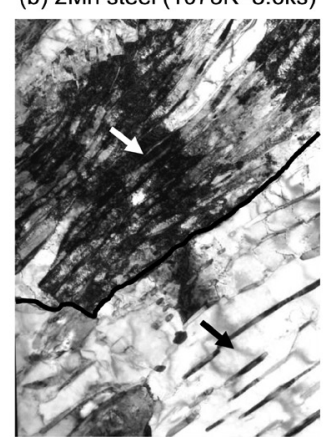

(c) $5 \mathrm{Mn}$ steel $(1073 \mathrm{~K}-10.8 \mathrm{ks})$

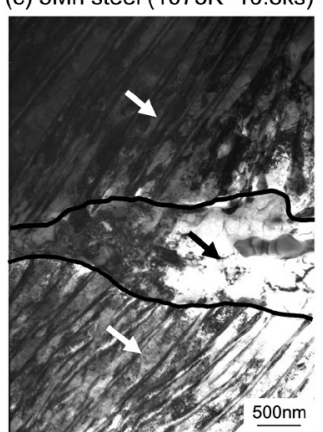

Fig. 5. TEM images in the specimens in which transformation has completed. Solid lines indicate boundaries between fine and coarse lamellar structures.

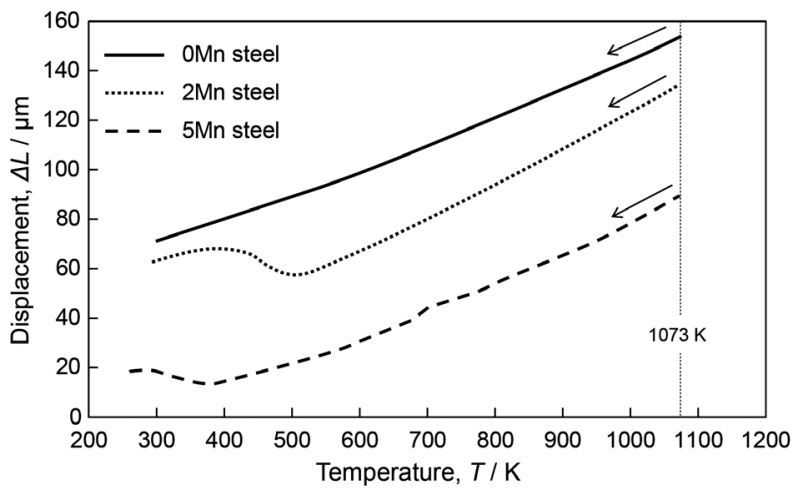

Fig. 6. Dilatometry curves for the specimens in which transformation has completed at $1073 \mathrm{~K}$.

び $280 \mathrm{~K}$ と測定された。5Mn鋼については，Mf点が室温以 下にあることから, Fig.2 (c) のX線回折によって検出され たオーステナイト相はマルテンサイト変態せずに残留した オーステナイトであると理解できる。以上の結果より，(i) $0 \mathrm{Mn}$ 鋼の均一なラメラ組織打よび $2 \mathrm{Mn}$ 鋼に打ける粗大ラ メラ組織の領域ならびに $5 \mathrm{Mn}$ 鋼における窒化物がまばら に分散した領域は，いずれも $\gamma \rightarrow \alpha+\mathrm{Cr}_{2} \mathrm{~N}$ 共析変態により 形成された組織であること，(ii) $2 \mathrm{Mn}$ 鋼打よび $5 \mathrm{Mn}$ 鋼にお ける高密度の転位を有する微細ラメラ組織の領域は, $\gamma_{1} \rightarrow$ $\gamma_{2}+\mathrm{Cr}_{2} \mathrm{~N}$ セ状析出の後の冷却時に $\gamma_{2}$ 相がマルテンサイ 卜変態して形成された組織であると結論できる。

\section{$3 \cdot 2$ 変態組織の結晶学的特徵}

Fig.7は, $1073 \mathrm{~K}$ で $0.3 \mathrm{ks}$ 保持した $5 \mathrm{Mn}$ 鋼の SEM 組織 (a) およびfcc相 (b) とbcc相 (c) の結晶方位マップを示して いる。SEM組織 (a) より, 黒破線で示した旧オーステナイ 卜粒界上から生成したラメラ組織が，白破線まで成長して いることがわかる。また同領域のオーステナイト相の結晶 方位マップ (b) から，ラメラ組織内に抽てもほとんどの オーステナイトがマルテンサイト変態せずに残存してお り，またそれが旧オーステナイト粒界を挟んで反対側の未 変態オーステナイト粒と同一の結晶方位を有していること がわかる。これは, Fe-25Cr-20Ni-0.6N合金で生成する（ $\gamma$ $\left.+\mathrm{Cr}_{2} \mathrm{~N}\right)$ セル状析出物 ${ }^{10)}$ の結晶学的特徵と一致する。こ こで，罒中赤矢印で示すマルテンサイト $\left(\alpha^{\prime}\right)$ およびオー ステナイト $(\gamma)$ について $\{110\}_{\alpha},\{111\}_{\gamma}$ および $\{111\}_{\alpha}$, $\{110\}_{\gamma}$ の極点図をそれぞれ作成した結果，Fig.8に示すよ うにマルテンサイトとオーステナイトはKurdjumov-Sachs $(\mathrm{K}-\mathrm{S})$ 関係 $\left((111)_{\gamma} / /(011)_{\alpha},[-101]_{\gamma} / /[-1-11]_{\alpha},\right)^{13)}$ を満た していることがわかった。K-S 関係は Fe-C系合金のマルテ ンサイトで多く観察される結晶方位関係であり, 本合金の セル状析出で生成する高窒素オーステナイトは, $\mathrm{Cr}_{2} \mathrm{~N}$ とラ メラ組織を形成しているが，その結晶学的な特徴は一般的 な炭素鋼マルテンサイトと同じであることがわかった。

Fig.9に恒温変態完了後の $2 \mathrm{Mn}$ 鋼の SEM 組織 (a) および 結晶方位マップ (b) を示す。SEM組織 (a) より Fig.4 (b) 


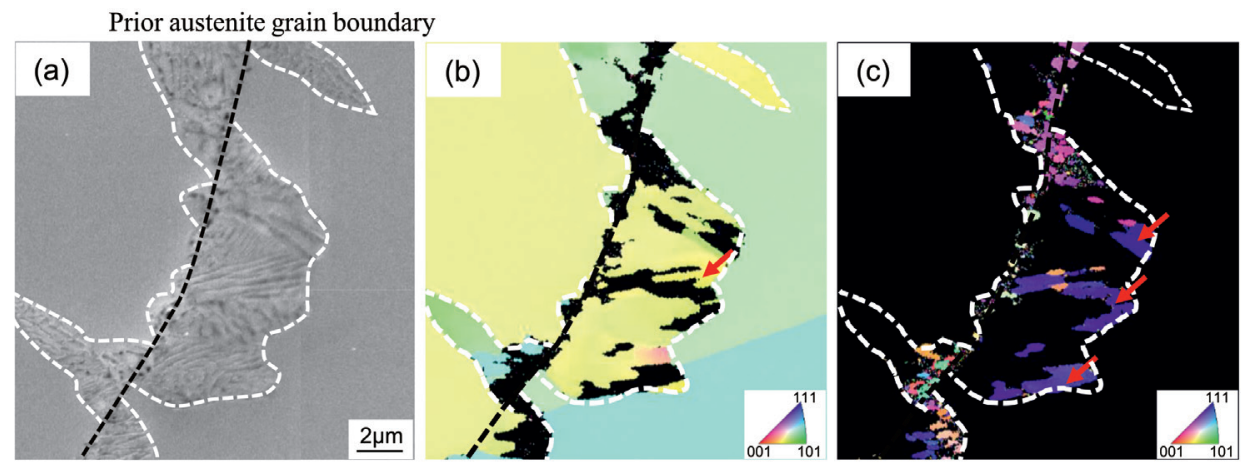

Fig. 7. SEM image (a), inverse pole figure maps of austenite (b) and ferrite (c) of the $5 \mathrm{Mn}$ steel with the isothermal heat treatment at $1073 \mathrm{~K}$ for $0.3 \mathrm{ks}$.

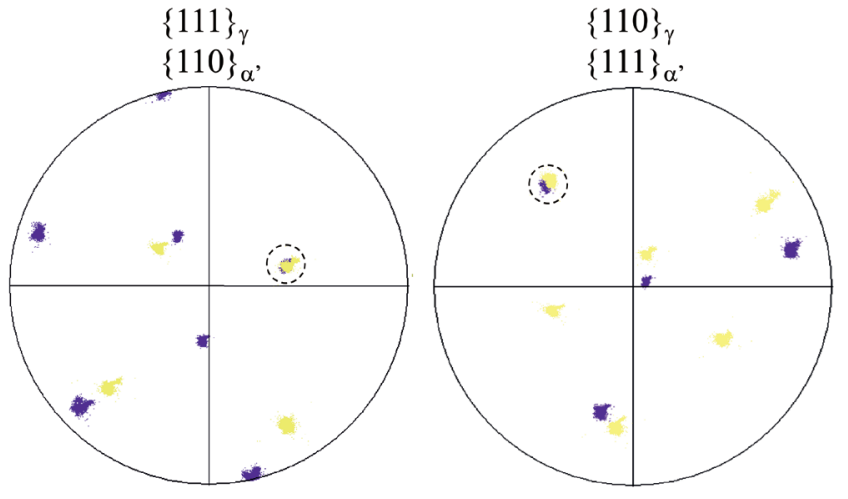

Fig. 8. Pole figures of $\{011\}_{\alpha^{\prime}},\{111\}_{\gamma}$ and $\{111\}_{\alpha^{\prime}},\{110\}_{\gamma}$ of the $5 \mathrm{Mn}$ steel with the isothermal heat treatment at $1073 \mathrm{~K}$ for $0.3 \mathrm{ks}$.

と同様に粗大ラメラ組織の領域と微細ラメラ組織の領域が 観察される。それぞれの領域の結晶方位マップ (b) に着目 すると, 粗大ラメラ組織の領域では結晶方位がほぼ同一で あるのに対して, 微細ラメラ組織の領域では結晶方位の異 なる板状の結晶粒が微細に分散していることがわかる。す なわち,この結果は, (i) 粗大ラメラ組織の領域に対応する 共析組織が, 比較的広い領域で同一のフェライト方位を有 する共析ブロック ${ }^{14)}$ から構成されること，(ii) 微細ラメラ 組織の領域に対応するマルテンサイト組織が, 変態時に形 成される微細なマルテンサイトブロック ${ }^{15)}$ から構成され ることを示している。

\section{4. 変態機構の考察}

Fig.10にThermo-Calc (Database:SSOL2) を用いて作成し た Fe-25Cr-0Mn-N (a)，Fe-25Cr-2Mn-N (b) およびFe-25Cr$5 \mathrm{Mn}-\mathrm{N}(\mathrm{c})$ 合金の平衡状態図を示す。いずれの鋼種におい ても $\left(\alpha+\mathrm{Cr}_{2} \mathrm{~N}\right)$ 二相域, $\left(\gamma+\mathrm{Cr}_{2} \mathrm{~N}\right)$ 二相域および $(\gamma+$ $\left.\alpha+\mathrm{Cr}_{2} \mathrm{~N}\right)$ 三相域が存在しているが, $\mathrm{Mn}$ 量の増加に伴い $\left(\alpha+\mathrm{Cr}_{2} \mathrm{~N}\right)$ 二相域が狭くなり, $\left(\gamma+\mathrm{Cr}_{2} \mathrm{~N}\right)$ 二相域打よび $\left(\gamma+\alpha+\mathrm{Cr}_{2} \mathrm{~N}\right)$ 三相域が低窒素側へ拡がっている。つま り, 本解析結果は, $\mathrm{Mn}$ の添加によってオーステナイトの安
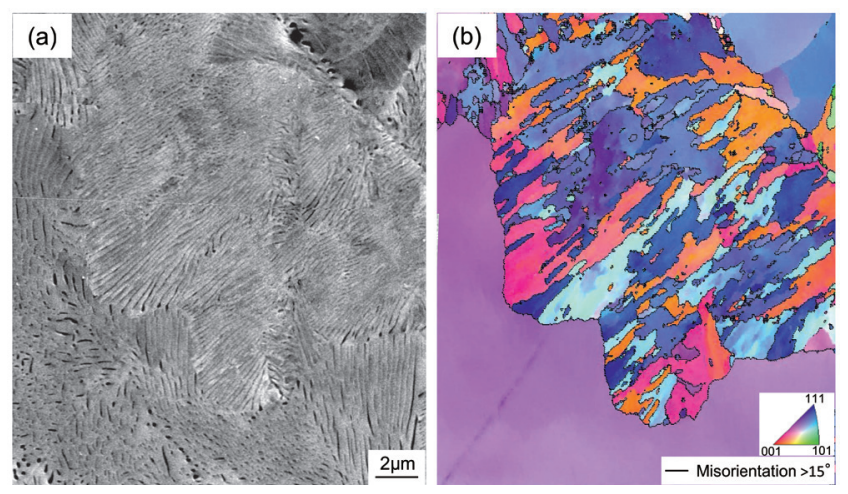

Fig. 9. SEM image (a) and inverse pole figure maps (b) of the $2 \mathrm{Mn}$ steel with the isothermal heat treatment at $1073 \mathrm{~K}$ for $3.6 \mathrm{ks}$.

定領域で生じるセル状析出が起こり易くなることを示唆し ており，実験結果とも一致する。本実験において，いずれ の鋼種も窒素を約 $1.1 \%$ 添加した試料を $1073 \mathrm{~K}$ で恒温保持 しているため, $0 \mathrm{Mn}$ 鋼は $\left(\alpha+\mathrm{Cr}_{2} \mathrm{~N}\right)$ 二相域, $2 \mathrm{Mn}$ 鋼打よ び $5 \mathrm{Mn}$ 鋼は $\left(\gamma+\alpha+\mathrm{Cr}_{2} \mathrm{~N}\right)$ 三相域にそれぞれ位置してい ることになる。Kikuchiらは， $\gamma_{1} \rightarrow \gamma_{2}+\mathrm{Cr}_{2} \mathrm{~N}$ セル状析出の 特徵として, 変態部への窒素の吸い上げ, 窒素の長距離拡 散が生じることにより, 未変態オーステナイト中の窒素濃 度が低下することを報告している ${ }^{10)}$ 。そのような現象が生 じると, オーステナイトの変態機構が変態の進行に伴い変 化する可能性も考えられる。そこで, $5 \mathrm{Mn}$ 鋼の変態時にお ける窒素の分布状態を調查した。Fig.11は, 5Mn 鋼の 1073 K-0.6 ks 恒温保持材の SEM 組織と, SEM 像中の Lineに沿つ て測定したEPMA窒素濃度プロファイルを示している。な お, 本実験で用いたEPMAのプローブ径は, 約 $1 \mu \mathrm{m}$ であり ラメラ間隔に対して著しく大きい。そのため, 析出部の窒 素濃度は, オーステナイトあるいはフェライト中の窒素濃 度ではなく $\mathrm{Cr}_{2} \mathrm{~N}$ を含めた析出部全体の窒素濃度を表して いる。変態界面から離れた $0 \sim 10 \mu \mathrm{m} の$ 未変態オーステナ イト領域では窒素はほぼ均一に固溶しており, 窒素濃度は 添加量の $1.1 \%$ にほぼ近い值を示している。それに対して,

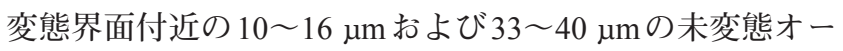


ステナイト領域では窒素濃度が平均組成よりも低下してお り，また $\gamma_{2}\left(\alpha^{\prime}\right)+\mathrm{Cr}_{2} \mathrm{~N}$ ラメラ領域内部では平均組成より も窒素濃度が高くなっている。これは，未変態オーステナ イト部から $\gamma_{2}+\mathrm{Cr}_{2} \mathrm{~N}$ 部へ窒素が流入していることを示唆 しており，本試料に拈いても窒素の長距離拡散が生じてい ることを意味している。ここで， $\left(\alpha+\mathrm{Cr}_{2} \mathrm{~N}\right)$ 領域に着目す ると, 窒素濃度が添加量よりも著しく低下していることが
わかる。 $\left(\alpha+\mathrm{Cr}_{2} \mathrm{~N}\right)$ 共析変態が $\gamma_{2}+\mathrm{Cr}_{2} \mathrm{~N}$ セル状析出の後 に生じると考えれば, $2 \mathrm{Mn}$ 鋼および $5 \mathrm{Mn}$ 鋼における変態機 構は, Fig.12に模式的に示すように説明される。恒温変態 が始まると，まず初めに $\gamma_{1} \rightarrow \gamma_{2}+\mathrm{Cr}_{2} \mathrm{~N}$ セル状析出により 旧 $\gamma$ 粒界に $\left(\gamma_{2}+\mathrm{Cr}_{2} \mathrm{~N}\right)$ ラメラ組織が形成される。この反 応は長距離拡散によるラメラ組織内への窒素の流入を伴う ため, 変態界面近傍の未変態オーステナイト領域で窒素濃 (a) OMn steel

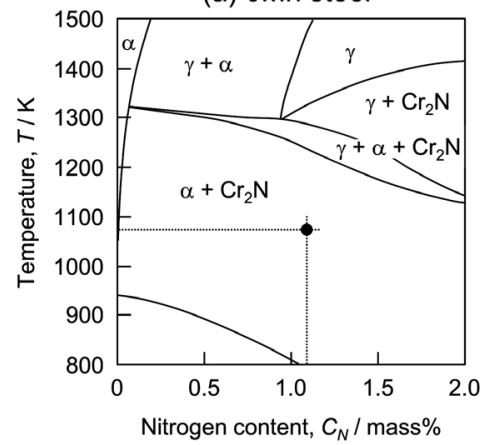

(b) $2 \mathrm{Mn}$ steel

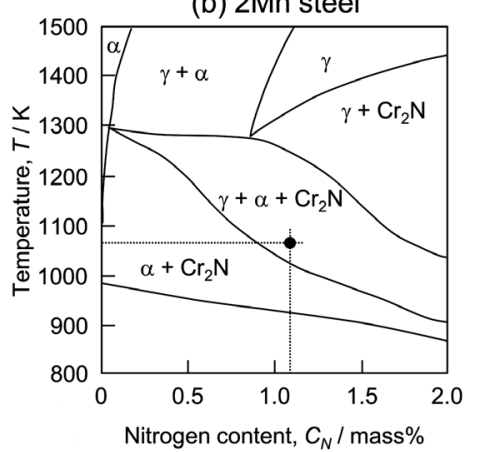

(c) $5 \mathrm{Mn}$ steel

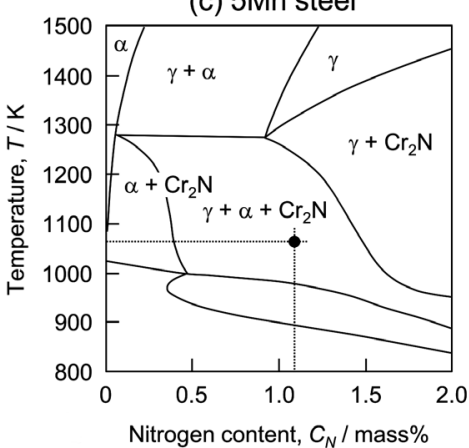

Fig. 10. Equilibrium phase diagrams of Fe-25Cr-N-0Mn (a), $-2 \mathrm{Mn}$ (b) and $-5 \mathrm{Mn}$ (c) alloys.

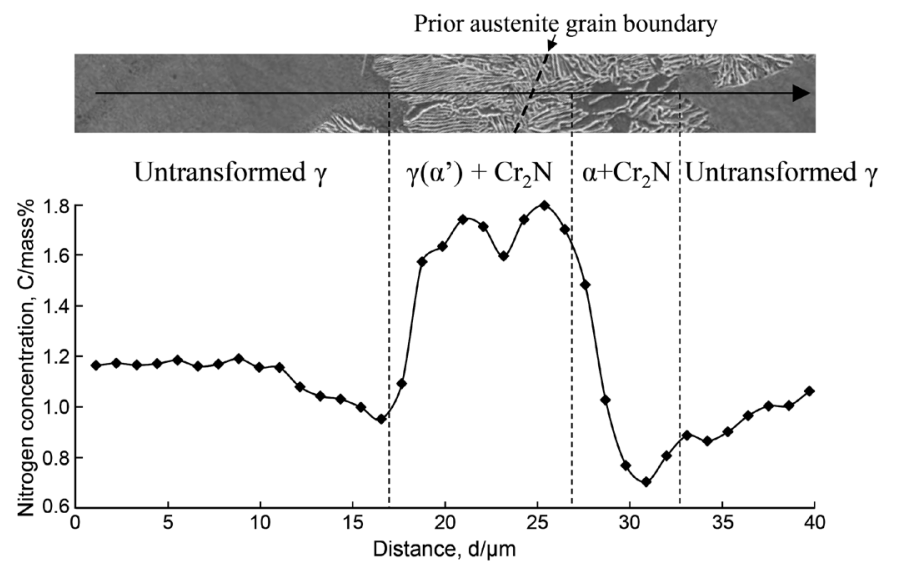

Fig. 11. Nitrogen concentration profile in the $5 \mathrm{Mn}$ steel with the isothermal heat treatment at $1073 \mathrm{~K}$ for $0.6 \mathrm{ks}$.

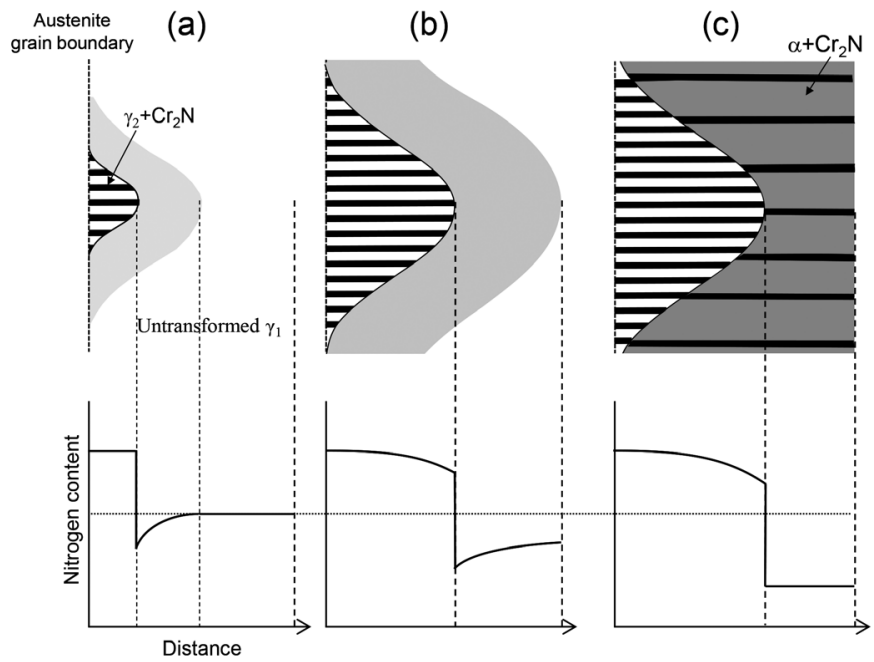

Fig. 12. Schematic illustration showing the transformation mechanism in the $2 \mathrm{Mn}$ and $5 \mathrm{Mn}$ steel. 
度が低下した窒素欠乏層が形成される (a)。七ル状析出の 進行により未変態オーステナイト部の窒素濃度が低下する と, 変態界面での窒素濃度もさらに低下する (b)。そして 界面近傍の未変態オーステナイトの安定度が損なわれるあ る組成にまで窒素濃度が低下した時点で, $\gamma_{1} \rightarrow \alpha+\mathrm{Cr}_{2} \mathrm{~N}$ 共析変態による $\left(\alpha+\mathrm{Cr}_{2} \mathrm{~N}\right)$ ラメラ組織の形成が開始する。 共析変態は, 窒素の長距離拡散を伴うことなく進行し, $(\alpha$ $\left.+\mathrm{Cr}_{2} \mathrm{~N}\right)$ 領域の平均窒素濃度がほぼ一定に維持されたまま 変態完了に至る $(\mathrm{c})$ 。以上のようなセル状析出から共析変 態への変態機構の遷移は, 状態図の高窒素側に $\gamma+\mathrm{Cr}_{2} \mathrm{~N}$ 領 域が存在し，低窒素側に $\alpha+\mathrm{Cr}_{2} \mathrm{~N}$ 領域が存在するような合 金系において発現する変態機構であると考えられ，セル状 析出のみが生じる合金 ${ }^{10)}$ と異なり，全てのオーステナイト が変態を完了する点に特徴がある。

\section{5. 結言}

$\mathrm{Mn}$ 量を0〜 5 mass\%の範囲で変化させた Fe-25Cr-Mn$1.1 \mathrm{~N}$ 合金の恒温変態に伴う相変態挙動打よび形成組織に ついて調査し，高窒素オーステナイトの相変態機構に及ほ す $\mathrm{Mn}$ 添加の影響について考察を行った結果，以下の知見 を得た。

1） $\mathrm{Mn}$ を添加していない Fe-25Cr-1.1N合金は，恒温保持に より共析変態を生じ, フェライトと $\mathrm{Cr}_{2} \mathrm{~N}$ からなるラメ ラ組織を生成する。Mn添加量の増加に伴い相変態は遅 延し，形成される組織は (フェライト $+\mathrm{Cr}_{2} \mathrm{~N}$ ) 共析ラメ ラ組織だけでなく, 比較的ラメラ間隔が小さい（マルテ ンサイト $\left.+\mathrm{Cr}_{2} \mathrm{~N}\right)$ ラメラ組織も形成されるようになる。 また Fe-25Cr-5Mn-1.1N 合金には残留オーステナイトが 存在する。
2) Fe-25Cr-2Mn-1.1NおよびFe-25Cr-5Mn-1.1N合金で観察 される（マルテンサイト $+\mathrm{Cr}_{2} \mathrm{~N}$ ) ラメラ組織は， $\gamma_{1} \rightarrow \gamma_{2}$ $+\mathrm{Cr}_{2} \mathrm{~N}$ セル状析出反応による (オーステナイト $\left(\gamma_{2}\right)+$ $\left.\mathrm{Cr}_{2} \mathrm{~N}\right)$ 組織の形成後, 冷却時に $\gamma_{2}$ がマルテンサイト変態 することによって形成される組織である。その際形成さ れるマルテンサイトは, 母相 $\gamma_{2}$ と K-S関係を有している。

3） Mn添加により出現するセル状析出は, 長距離拡散によ る窒素の流入を伴うため, 未変態オーステナイト部の窒 素濃度は変態の進行と共に低下する。その結果, 変態機 構がセル状析出から共析変態へ遷移する。

\section{文献}

1 ) S.Kubota and Y.Tomota: CAMP-ISIJ, 10 (1997), 538.

2 ) 道沢浩一郎, 小林裕 : 第 190 回西山記念技術講座, 日本鉄鋼協 会編, 東京, (2006), 71 .

3 ) T.Nakazawa, S.Hoshino, K.Yamaguchi and Y.Katada: Tetsu-toHagané, 93 (2007), 240.

4 ) N.Nakada, N.Hirakawa, T.Tsuchiyama and S.Takaki: Scr. Mater, 57 (2007), 153 .

5 ) N.Hirakawa, N.Nakada, T.Tsuchiyama and S.Takaki: CAMP-ISIJ, 19 (2006), 1090.

6 ) H.C.Holm, P.J.Uggowitzer and M.O.Speidel: Scr. Metall., 21 (1987), 513.

7 ) F.Vanderschave, R.Tailard and J.Foct: J. Mater. Sci., 30 (1995), 6035.

8 ) N.C.Santhi Srinivas and V.V.Kutumbarao: Scr. Mater, 37 (1997), 285.

9 ) M.Tanaka, O.Miyagawa and D.Fujishiro: J. Jpn. Inst. Met., 41 (1977), 11.

10) M.Kikuchi: Netsu Shori, 36 (1996), 197.

11) T.Tsuchiyama, T.Ito, K.Kataoka and S.Takaki: Metall. Mater. Trans. A, 34 (2003), 2591.

12) A.Sieverts: Z. Metallkd., 21 (1929), 37.

13) G.Kurdjumov and G.Sachs: Z. Phys., 64 (1930), 325.

14) T.Takahashi, M.Nagumo and Y.Asano: J. Jpn. Inst. Met., 42 (1978), 716.

15) J.M.Marder and A.R.Marder: Trans ASM., 62 (1969), 1. 